\title{
Studies in Immunochemistry.
}

\section{THE AMINO ACID COMPOSITION OF THE HUMAN BLOOD-GROUP A, B, H AND Le ${ }^{a}$ SPECIFIC SUBSTANCES*}

\author{
By A. PUSZTAI AND W. T. J. MORGAN \\ The Lister Institute of Preventive Medicine, London, S.W. 1
}

(Received 11 March 1963)

Over the last decade much work has been done to determine the chemical structure and immunological function of the carbohydrate components of the human blood-group-specific substances. During the same period, however, little serious attention was given to establishing the nature and significance of the amino acid-containing moiety that occurs in all preparations and is not directly responsible for the characteristic blood-group specificity of these substances.

Earlier and rather incomplete observations on the amino acid composition of the specific substances (Landsteiner \& Harte, 1940, 1941 ; Freudenberg, Walch \& Molter, 1940; Morgan \& King, 1943; Brand \& Saidel, 1946; Bendich, Kabat \& Bezer, 1946; Morgan, 1947; Aminoff, Morgan \& Watkins, 1950; Gibbons \& Morgan, 1954; Carsten \& Kabat, 1956) indicated that amino acids were always present in the most highly purified materials, whether of animal or human origin, and that the amino acid-containing part of each substance contained threonine, serine and proline much in excess of that recorded for other proteins. In all materials the aromatic amino acids were poorly represented and sulphur-containing amino acids were probably absent. However, in the light of more recent studies (Pusztai \& Morgan, 1961; and unpublished work) on the homogeneity of blood-group-specific substances, it seemed desirable to determine more exactly the quantitative amino acid composition of blood-group-specific mucopolysaccharide preparations that had undergone further and more rigorous purification and that were free from demonstrable amino acid-containing impurities. The results of the analysis of several preparations of each of the $\mathrm{A}, \mathrm{B}, \mathrm{H}$ and $\mathrm{Le}^{\mathrm{a}}$ active blood-group substances are given in the present paper.

\section{EXPERIMENTAL}

Blood-group-specific substances. These were prepared from human ovarian-cyst fluids by procedures, or slight modifications of them, described by Morgan \& King (1943) and Gibbons, Morgan \& Gibbons (1955). The substances were purified further by fractionation with saturated

* Part 21: Morgan \& Pusztai (1961). ammonium sulphate at $60^{\circ}$, and the resulting fractions, after thorough dialysis against water at $1-2^{\circ}$, were fractionated from solution $(1 \%, w / v)$ by ethanol, dialysed, centrifuged at $30000 \mathrm{~g}$ for $1 \mathrm{hr}$. and freeze-dried (Pusztai \& Morgan, 1961). A commercial preparation of pig gastric mucin made from a pool of many individual stomach linings and possessing both $A$ and $H$ activity was purified as described for the ovarian-cyst mucin.

Physical examination. All specific substances that were analysed for their amino acid composition behaved as materials essentially free from gross heterogeneity when they were examined $(a)$ by ultracentrifuging in the Svedberg oil-driven centrifuge (Kekwick, 1950) or, with later materials, in a Spinco model $\mathrm{E}$ ultracentrifuge and $(b)$ by electrophoresis, as described by Kekwick (1950) and Caspary (1954).

Determination of nitrogen. Kjeldahl nitrogen was determined in the apparatus of Markham (1942) with bromocresol green-methyl red indicator (Ma \& Zuazaga, 1942).

Determination of amino sugars. A modification (Rondle \& Morgan, 1955) of the method of Elson \& Morgan (1933) was used. The results are expressed as glucosamine base.

Determination of sialic acid. This was carried out by the thiobarbituric acid method of Warren (1959) after the material had been heated at $80^{\circ}$ in $0.1 \mathrm{~N}-\mathrm{H}_{2} \mathrm{SO}_{4}$ for $1 \mathrm{hr}$. to liberate the sialic acid.

Hydrolysis. The materials, which were freeze-dried, were further dried over $\mathrm{P}_{2} \mathrm{O}_{5}$ for $30 \mathrm{~min}$. at $78^{\circ}$ and $1-2 \mathrm{~mm}$. $\mathrm{Hg}$ pressure before analysis. The substances were hydrolysed in a large volume of $6 \mathrm{~N}-\mathrm{HCl}$. To determine the most satisfactory conditions the temperature and time of hydrolysis were varied in different experiments. At $100^{\circ}$ a few peptides survived heating for $24 \mathrm{hr}$., whereas at temperatures above $117^{\circ}$ there was an enhanced destruction of certain of the amino acids. The main hydrolysis experiments were therefore made by refluxing at $114-117^{\circ}$ a solution of the substance (about $15 \mathrm{mg}$.) in $150 \mathrm{ml}$. of $6 \mathrm{~N}-\mathrm{HCl}$. After hydrolysis was complete, the solution was evaporated to dryness in vacuo at $30^{\circ}$, dissolved in a few millilitres of water and again evaporated to dryness. The solution in water and evaporation to dryness was repeated three times and the material finally taken up in a small volume of citrate buffer, $\mathrm{pH} 2.2\left(0.2 \mathrm{M}\right.$ with respect to $\mathrm{Na}^{+}$ions), for application to the resin column.

Determination of amino acids. The method used was essentially that described by Moore, Spackman \& Stein (1958), with some slight, but important, modifications. The buffers employed did not contain BRIJ 35 detergent or thiodiglycol. The acidic and neutral amino acids were resolved on columns $(150 \mathrm{~cm} . \times 0.9 \mathrm{~cm}$.) of ion-exchange resin Aminex (MS Blend; Q 150 grade; particle size 31- 
$45 \mu$ ) (Moore et al. 1958). The basic amino acids were separated on a column (50 cm. $\times 0.9 \mathrm{~cm}$.) of Aminex (MS Blend; Q 50 grade; particle size 25-31 $\mu$ ) in place of the shorter column $(15 \mathrm{~cm} . \times 0.9 \mathrm{~cm}$.) recommended by Moore et al. (1958). Two buffers were used. The first was citrate buffer, $\mathrm{pH} 4 \cdot 18 \pm 0.02\left(0.38 \mathrm{M}\right.$ with respect to $\mathrm{Na}^{+}$ions $)$, and the elution was started at $30^{\circ}$. Replacement of the citrate buffer, $\mathrm{pH} 4 \cdot 26 \pm 0 \cdot 02$, originally recommended by Moore et al. (1958) by the more acidic buffer ( $\mathrm{pH} 4 \cdot 18 \pm 0 \cdot 02$ ), brought about a better separation of lysine from the large ammonia-containing peak and allowed a sharper separation of the hexosamines from each other. The ammonia-containing peak was recovered after 110 tubes, each containing $2 \mathrm{ml}$., had been collected. The temperature of the heating jacket was then raised to $50^{\circ}$ and histidine was recovered before the 150th fraction was reached. At this point in the elution the $\mathrm{pH}$ of the buffer was changed to $6 \cdot 5 \pm 0 \cdot 1$, the $\mathrm{Na}+$ ion concentration remaining at $0.38 \mathrm{M}$. The elution was continued for a further 100 tubes to include arginine, the last amino acid to be recovered. The fractions were collected by an electronic drop-counting fraction collector.

The exact amount of each fraction collected was determined and frequently checked by weighing four or five fractions selected at random. The order and position of each amino acid eluted from the column were established with an artificial mixture of amino acids. Control mixtures in which known amounts of amino acids and sugars were subjected to the hydrolytic conditions ( $6 \mathrm{~N}-\mathrm{HCl}$ at $114-117^{\circ}$ for $24 \mathrm{hr}$.) and chromatographed on the resin columns by the standard procedure were also examined.

The fractions obtained from the column were subjected to the quantitative ninhydrin test, described by Moore \& Stein (1954), and the extinctions at $570 \mathrm{~m} \mu$ measured in a Unicam SP. 200 instrument. DL- $\alpha$-Alanine (Organic Analytical Standard; British Drug Houses Ltd.) was used as the amino acid standard. The extinctions of the proline eluates were measured at $\mathbf{4 4 0} \mathrm{m} \mu$. The individual readings, after subtracting the base-line value associated with each peak, were added together, and the amount of each amino acid was calculated. The results are given as $\mathrm{g}$. of amino acid/100 g. of blood-group substance, and as $\mu$ moles of amino acid $/ 100 \mu$ moles of total amino acids determined. The recoveries for the amino acids were obtained from a comparison of the total $\mathrm{N}$ determined (by the Kjeldahl method) and the $\mathrm{N}$ value obtained by adding together the hexosamine $\mathrm{N}$, sialic acid $\mathrm{N}$ and the amino acid $\mathrm{N}$. The last value was obtained by assuming that the $N$ content of the amino acid-containing portion of the blood-group substance was $16 \%$. The recoveries in most instances were satisfactory $(100 \pm 5 \%)$.

In several instances the individual component amino acids were separated and isolated from large resin columns $(150 \mathrm{~cm} . \times 2.0 \mathrm{~cm}$.). Formate or acetate buffers were used at the same $\mathrm{Na}^{+}$ion concentration and $\mathrm{pH}$ as those employed on the analytical columns. The buffer acids were removed by volatilization in vacuo in conc. $\mathrm{HCl}$ and the resulting $\mathrm{NaCl}$ by its insolubility in conc. $\mathrm{HCl}$. The saltfree components were identified as follows: Aspartic acid and glutamic acid by high-voltage paper electrophoresis (Ryle, Sanger, Smith \& Kitai, 1955) in pyridine-acetate buffers, $\mathrm{pH} 3.6$ and 6.4 (voltage gradient, 40-50v/cm.; time 1-2 hr.). The papers containing the selected buffer were immersed in 'white spirit', which was maintained during electrophoresis at about $20^{\circ}$ by cooling coils. Amino acids were also identified by paper chromatography with butan-1-ol-acetic acid-water (4:1:5, by vol.) and phenolsaturated water-ammonia. Serine and threonine were identified by chromatography and by oxidation with periodate to formaldehyde and acetaldehyde respectively (Frisell, Meech \& Mackenzie, 1954; Rees, 1946). Proline was identified by its characteristic yellow colour with ninhydrin. Hydroxyproline was not detected with ninhydrin or with the specific Neuman-Logan test in fractions corresponding in position to those that might be expected to contain hydroxyproline. Tyrosine and phenylalanine were confirmed by their ultraviolet-absorption spectra. Basic amino acids were identified by comparing their behaviour with authentic specimens of histidine, lysine and arginine (Ryle et al. 1955) on high-voltage paper electrophoresis. Histidine was also confirmed by the Pauly diazo reaction (Ames \& Mitchell, 1952, 1955), and arginine by the Sakaguchi test (Jepson \& Smith, 1953). Tests were made to confirm that no overlap of the individual amino acids occurred in the eluate fractions comprising the amino acid peaks.

Determination of ammonia. The ammonia liberated from the amino acids or blood-group substances during hydrolysis with $6 \mathrm{~N}-\mathrm{HCl}$ at $114-117^{\circ}$ was determined colorimetrically with Nessler reagent (cf. Dawson, Elliott, Elliott \& Jones, 1959). The sample taken from the reaction mixture was diluted to $5 \mathrm{ml}$. to give an ammonia concentration of between 0 and $30 \mu \mathrm{g}$./test and to this $5 \mathrm{ml}$. of Nessler reagent was added, shaken and the extinction at $425 \mathrm{~m} \mu$ read immediately in a cell of light-path $1 \mathrm{~cm}$. A calibration curve was obtained with known amounts of $\left(\mathrm{NH}_{4}\right)_{2} \mathrm{SO}_{4}$ in the range $0-30 \mu \mathrm{g}$. of ammonia/test sample and Nessler reagent mixed under identical conditions. The curve is linear between 0 and $30 \mu \mathrm{g}$. of ammonia/test sample. To compensate for the ammonia uptake of the boiling $6 \mathrm{~N}-\mathrm{HCl}$ from the atmosphere, the same amount of $\mathrm{HCl}$ was heated under identical conditions without amino acid added, and the ammonia determined was taken as an ammonia blank and subtracted from the experimental readings.

\section{RESULTS}

In the light of the experience of others (Dustin, Czajkowska, Moore \& Bigwood, 1953), the hydrolyses were carried out in a large volume of $6 \mathrm{~N}$ hydrochloric acid to diminish as much as possible the formation of humin. The large amount of carbohydrate in the blood-group substances rendered sulphuric acid an unsatisfactory hydrolytic reagent because of the strong side reactions that lead to extensive decomposition of amino acids and to the formation of humin.

Preliminary experiments were made to determine the rate of destruction of those amino acids known to be most sensitive to acid decomposition, namely, serine, threonine and aspartic acid. The amino acids were heated at $114-117^{\circ}$ with $6 \mathrm{~N}$-hydrochloric acid for up to $72 \mathrm{hr}$. and were found to suffer a linear rate of destruction as measured by the formation of ammonia. The loss was considerable over $72 \mathrm{hr}$. The results (Fig. 1) include those 
obtained for glutamic acid, which is relatively stable under the conditions chosen. Independent evidence for the extent of destruction of serine was obtained by determining the amount of this amino acid that survived by oxidation with periodate and measurement of the formaldehyde liberated. The amount of serine remaining intact after heating with acid was similar for each method, which indicated that the destruction occurred by deamination only. As serine was the amino acid most extensively destroyed, the rate of destruction was determined at $114-117^{\circ}$, at $100^{\circ}$ and at about $130^{\circ}$ : the amount of destruction was considerable, even at $100^{\circ}$. The three amino acids, serine, threonine and aspartic acid, were also heated separately in $6 \mathrm{~N}$-hydrochloric acid at $114-117^{\circ}$ with the addition of about 100 times their weight of fucose and galactose, and the amount of each individual amino acid surviving was determined: the presence of a large excess of these two neutral sugars during hydrolysis did not alter significantly the amount of destruction.

To determine whether the rate of destruction of these amino acids was appreciably different from that occurring when they were liberated during hydrolysis of the intact blood-group substances, the specific substances were hydrolysed with $6 \mathrm{~N}$ hydrochloric acid at $114-117^{\circ}$ for 24,48 and $72 \mathrm{hr}$., and the amino acids formed were separated on ionexchange resin columns and determined as described above (Fig. 2).

The rates of liberation of serine, threonine and aspartic acid as free amino acids from the bloodgroup substances were determined after heating the specific substances for $2,4,8,24,48$ and $72 \mathrm{hr}$. in $6 \mathrm{~N}$-hydrochloric acid at $114-117^{\circ}$ (Fig. 3).

Quantitative amino acid analyses were carried out in duplicate (or triplicate) on A substance

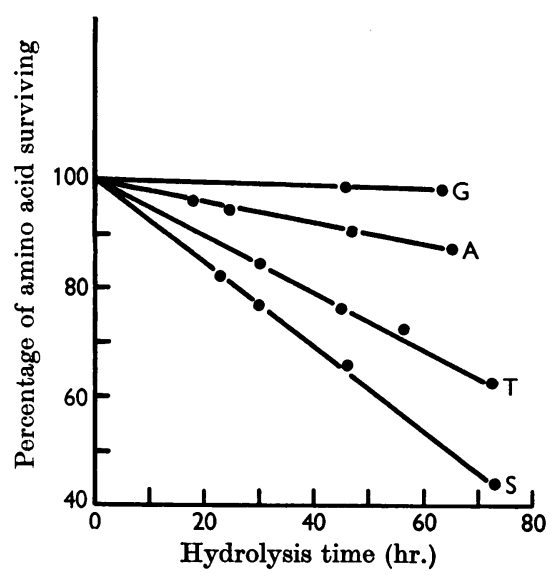

Fig. 1. Rate of destruction of glutamic acid (G), aspartic acid (A), threonine (T) and serine (S) on heating with $6 \mathrm{~N}$ $\mathrm{HCl}$ at $114-117^{\circ}$ for different times. (eight preparations), B substance (three preparations), $H$ substance (five preparations) and $\mathbf{L e}^{\mathrm{a}}$ substance (five preparations). Each material was isolated from a cyst fluid obtained from a different individual. A preparation of $\mathbf{A}$ and $\mathbf{H}$ active mucopolysaccharide obtained from hog gastric mucin (Morgan \& King, 1943) was included for comparison. The results obtained are summarized in Tables 1-5. The values given for serine, threonine and aspartic acid are corrected for the losses occurring on hydrolysis.

Examination of the products of hydrolysis recovered from the resin columns revealed that some of the early fractions that appeared before aspartic acid contained an acidic material reacting with ninhydrin and behaving in some respects like hydroxyproline. The material, which gave a similar but not identical Neuman-Logan reaction, absorbed strongly at $400-450 \mathrm{~m} \mu$ instead of $560 \mathrm{~m} \mu$ characteristic of hydroxyproline (Neuman \& Logan, 1950; Martin \& Axelrod, 1953); it was not hydroxyproline but was most probably an acidic degradation product of the amino sugars which had a structure similar to that of hydroxyproline.

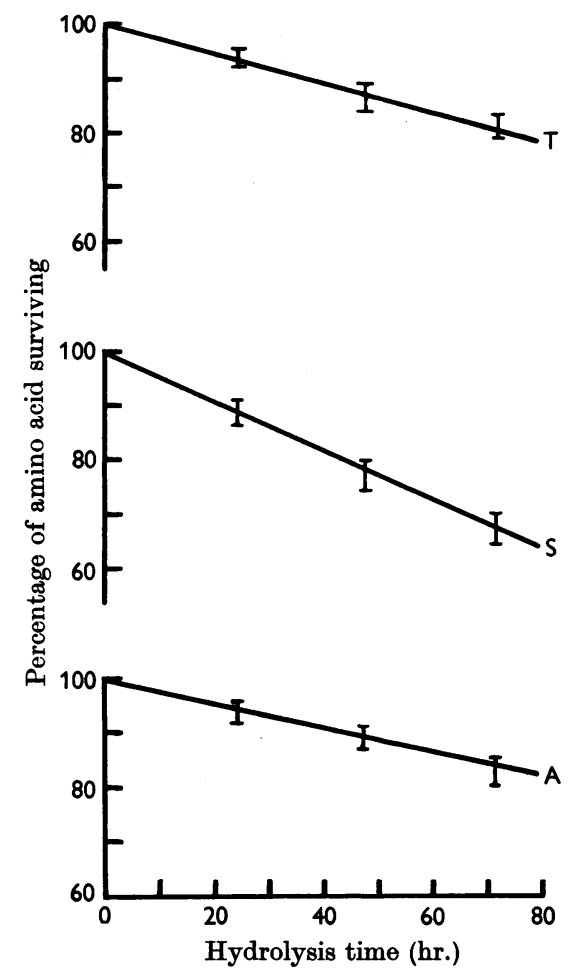

Fig. 2. Amounts of threonine (T), serine (S) and aspartic acid (A) in the hydrolysis products when blood-group substance was heated in $6 \mathrm{~N}-\mathrm{HCl}$ at $114-117^{\circ}$ for 24,48 and $72 \mathrm{hr}$. 
Ammonia was always found in considerable amounts in the acid-hydrolysis products and arose mainly from the extensive decomposition of the amino sugars, which were always present in large amounts, and from the limited deamination of the amino acids.

When the acid-hydrolysis products of the specific substances were separated on the standard $15 \mathrm{~cm}$. resin column, as recommended by Moore et al. (1958) for the separation and determination of basic amino acids, the lysine fraction was not completely separated from an unidentified material (Fig. 4). The satisfactory separation of the lysine was achieved, however, by employing a $50 \mathrm{~cm}$. column of resin, a more acidic buffer ( $\mathrm{pH} \mathrm{4.18)}$ and a lower temperature $\left(30^{\circ}\right)$ for elution. These modifications in technique resolved the unknown material into three distinct components that were subsequently isolated in a large-scale experiment. The same substances were formed from glucosamine or galactosamine, or a mixture of these amino sugars, when they were heated in $6 \mathrm{~N}$-hydrochloric acid at $114-117^{\circ}$ for $24 \mathrm{hr}$. The artifacts were resolved by chromatography on the $50 \mathrm{~cm}$. resin column. The substances were not contained in the acid hydrolysates of blood-group substances under conditions

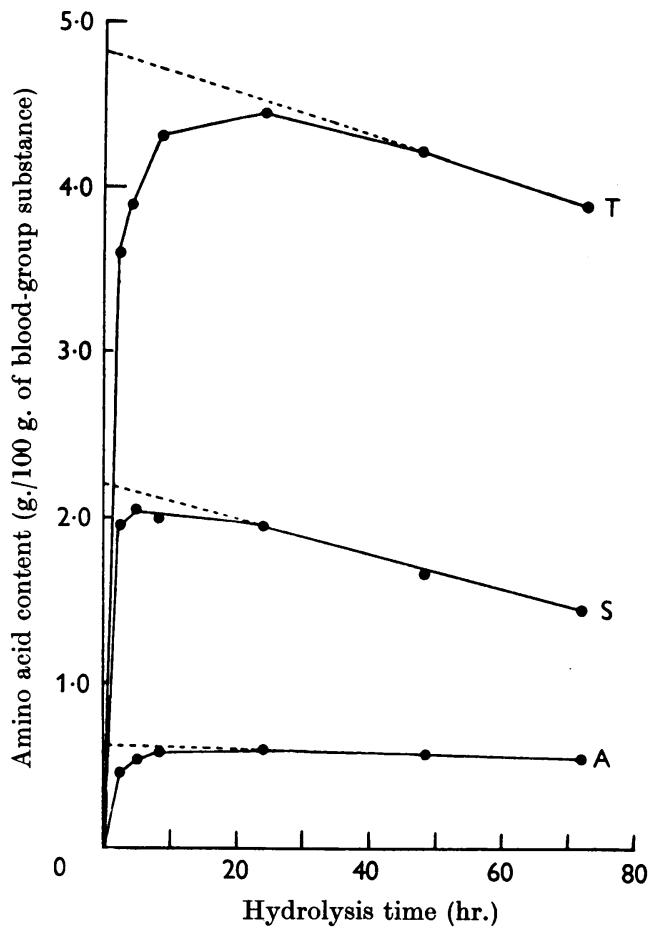

Fig. 3. Rate of liberation of threonine $(T)$, serine $(S)$ and aspartic acid (A) on hydrolysis of blood-group substance in $6 \mathrm{~N}-\mathrm{HCl}$ at $114-117^{\circ}$. $\left(0.5 \mathrm{~N}\right.$-hydrochloric acid at $100^{\circ}$ for $16 \mathrm{hr}$.) known to liberate, but not destroy, the hexosamines. Similarly the unidentified substances were not formed when the amino sugars were heated under the same conditions. The three unidentified substances are therefore presumably not components of the bloodgroup-specific mucopolysaccharides, but are artifacts formed from the glucosamine or galactosamine, or both, during hydrolysis of the specific substances with $6 \mathrm{~N}$-hydrochloric acid at $114-117^{\circ}$.

The basic amino acids, when separated on the long $(50 \mathrm{~cm}$.) resin column, appear in the eluate after the large ammonia-containing peak. Welldefined lysine and histidine peaks, sharply separated and with smooth and acceptable base lines, were readily obtained (Fig. 5).

\section{DISCUSSION}

Reliable values for the quantitative amino acid analysis of preparations of human blood-group substances could not be obtained until the extent to which the amino acids were destroyed during hydrolysis of the substances was known. Those amino acids, namely serine, threonine and aspartic acid, that were most readily destroyed by $6 \mathrm{~N}$-hydrochloric acid at $114-117^{\circ}$ were therefore determined after heating them for 24, 48 and $72 \mathrm{hr}$. with and without the addition of a large excess of fucose and galactose. The results in both sets of experiments were closely similar and indicated that the rate of destruction was linear for each of the amino acids, and that, after $24 \mathrm{hr}$. of digestion with acid, they suffered average losses of $18 \cdot 5,12 \cdot 3$ and $4.6 \%$ respectively.

The rates of destruction of the amino acids, serine, threonine and aspartic acid, during hydrolysis of the blood-group substances with $6 \mathrm{~N}$-hydrochloric acid at $114-117^{\circ}$ were also determined and were linear between 24 and $72 \mathrm{hr}$. (Fig. 2). The amounts of destruction in $24 \mathrm{hr}$. of the 3 amino acids determined from these values linearly extrapolated to $0 \mathrm{hr}$. were $10 \cdot 6,6 \cdot 4$ and $5.9 \%$ respectively. The extent of destruction of serine and threonine is less than is found for these amino acids after they had been heated alone (Fig. 1) under the same conditions. This protection from destruction may be due to the high concentration of ammonia derived from the decomposition of the amino sugars always present in the hydrolysis products of the blood-group substances. Before a correction for the amount of these amino acids destroyed could be applied, however, it was necessary to know that they were liberated as single amino acids early in the hydrolysis of the blood-group substances. The results (Fig. 3) of the appropriate hydrolysis experiments for shorter heating times than $24 \mathrm{hr}$. indicated that $80-90 \%$ of these amino acids were liberated as 


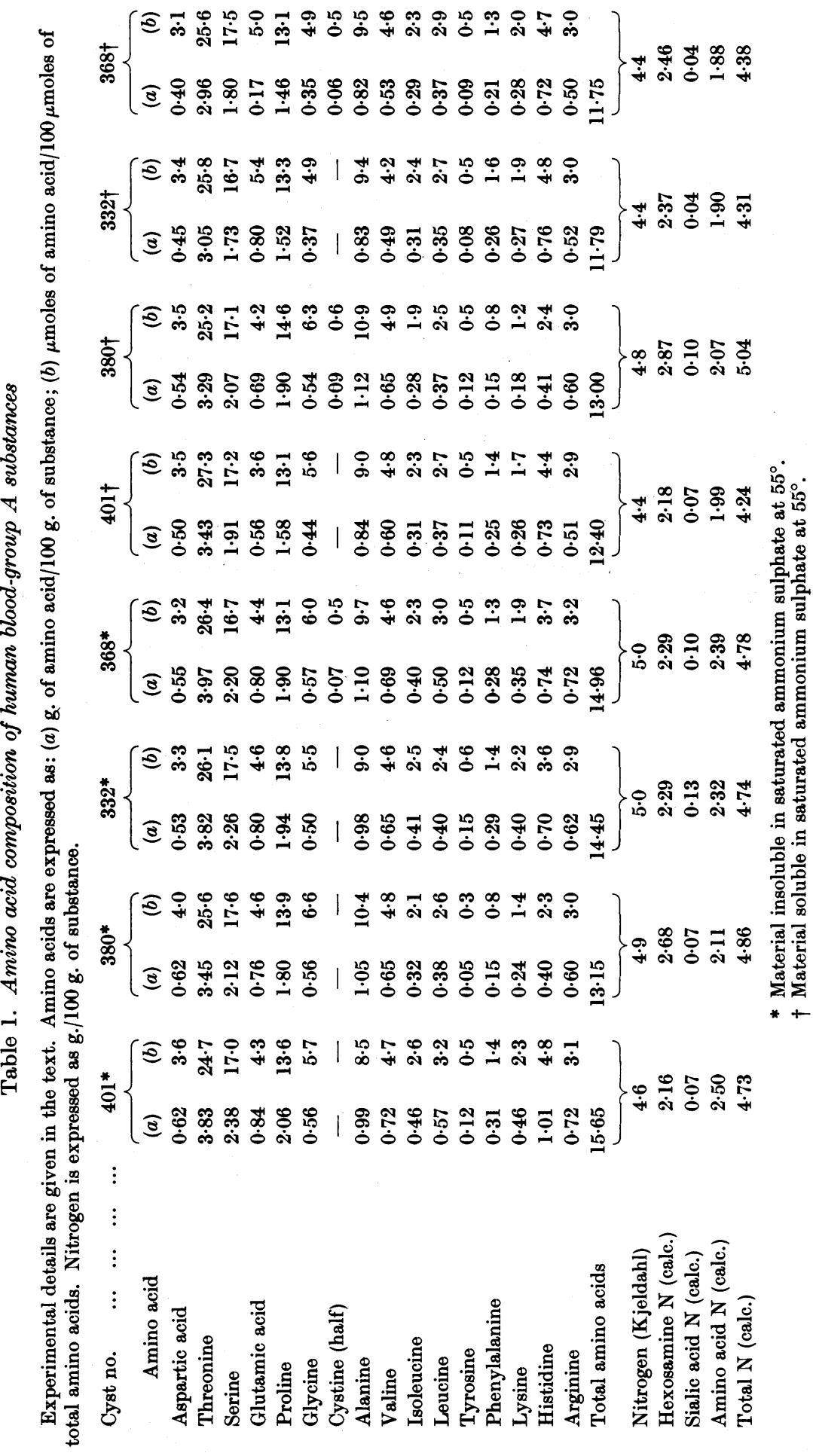


Table 2. Amino acid composition of human blood-group $B$ substances

Experimental details are given in the text. Amino acids are expressed as: (a) g. of amino acid/100 g. of substance; (b) $\mu$ moles of amino acid/100 $\mu$ moles of total amino acids. Nitrogen is expressed as g./100 g. of substance.

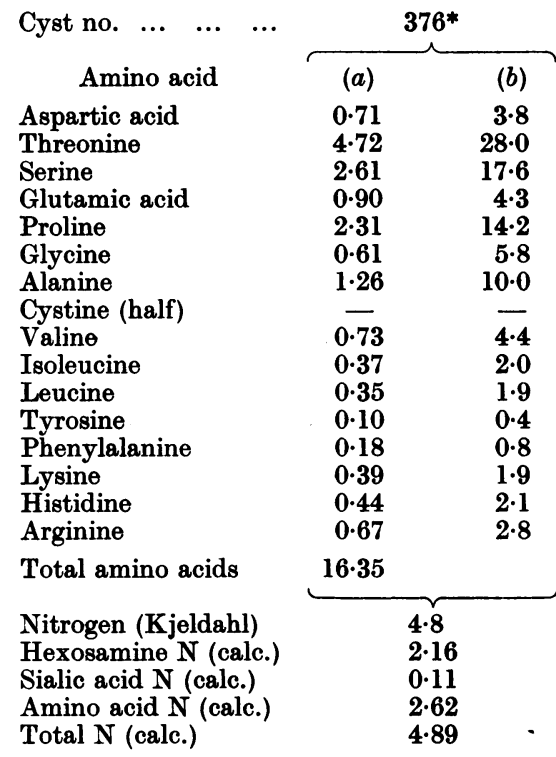

\begin{tabular}{|c|c|}
\hline \multicolumn{2}{|c|}{$413^{*}$} \\
\hline$(a)$ & (b) \\
\hline $\begin{array}{l}0.79 \\
3 \cdot 80 \\
1.98 \\
0 \cdot 73 \\
2 \cdot 00 \\
0 \cdot 58 \\
1 \cdot 21 \\
0 \cdot 11 \\
0 \cdot 68 \\
0 \cdot 31 \\
0 \cdot 34 \\
0 \cdot 15 \\
0 \cdot 28 \\
0 \cdot 25 \\
0 \cdot 51 \\
0 \cdot 66\end{array}$ & $\begin{array}{r}4 \cdot 8 \\
25 \cdot 9 \\
15 \cdot 6 \\
4 \cdot 0 \\
14 \cdot 2 \\
6 \cdot 2 \\
10 \cdot 9 \\
0 \cdot 7 \\
4 \cdot 7 \\
1 \cdot 9 \\
2 \cdot 0 \\
0 \cdot 7 \\
1 \cdot 4 \\
1 \cdot 4 \\
2 \cdot 6 \\
3.0\end{array}$ \\
\hline $14 \cdot 38$ & \\
\hline & \\
\hline
\end{tabular}

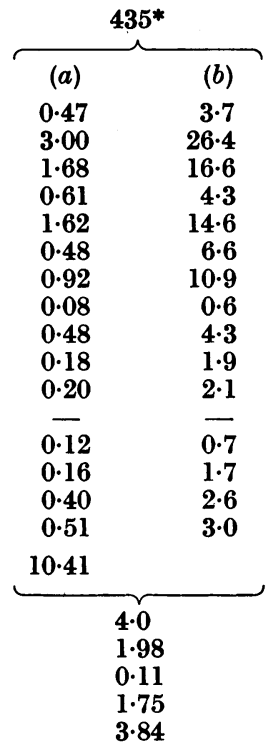

* Material soluble in saturated ammonium sulphate at $55^{\circ}$.

Table 3. Amino acid composition of human blood-group $H$ substances

Experimental details are given in the text. Amino acids are expressed as: (a) g. of amino acid/100 g. of substance; (b) $\mu$ moles of amino acid/100 $\mu$ moles of total amino acids. Nitrogen is expressed as g./100 g. of substance.

Cyst no.

Amino acid

Aspartic acid

Threonine

Serine

Glutamic acid

Proline

Glycine

Alanine

Cystine (half)

Valine

Isoleucine

Leucine

Tyrosine

Phenylalanine

Lysine

Histidine

Arginine

Total amino acids

Nitrogen (Kjeldahl)

Hexosamine $\mathrm{N}$ (calc.)

Sialic acid $\mathbf{N}$ (calc.)

Amino acid N (calc.)

Total N (calc.)

\begin{tabular}{|c|c|c|c|}
\hline \multicolumn{2}{|c|}{$277^{*}$} & \multicolumn{2}{|c|}{$241^{*}$} \\
\hline$(a)$ & (b) & $(a)$ & (b) \\
\hline 0.53 & $2 \cdot 6$ & 0.61 & $3 \cdot 0$ \\
\hline 5.42 & $29 \cdot 8$ & $5 \cdot 11$ & $28 \cdot 8$ \\
\hline $3 \cdot 25$ & $20 \cdot 1$ & 2.92 & $18 \cdot 6$ \\
\hline 0.76 & $\mathbf{3} \cdot \mathbf{3}$ & $0 \cdot 89$ & $3 \cdot 9$ \\
\hline $2 \cdot 52$ & $14 \cdot 2$ & $2 \cdot 52$ & $14 \cdot 4$ \\
\hline 0.58 & 5.0 & 0.61 & $5 \cdot 4$ \\
\hline $1 \cdot 30$ & $9 \cdot 5$ & $1 \cdot 30$ & $9 \cdot 7$ \\
\hline $0 \cdot 10$ & 0.5 & 0.11 & 0.6 \\
\hline 0.85 & $4 \cdot 7$ & 0.80 & $4 \cdot 5$ \\
\hline 0.53 & $2 \cdot 6$ & 0.41 & $2 \cdot 1$ \\
\hline 0.40 & 1.9 & 0.37 & 1.9 \\
\hline 0.05 & 0.2 & $0 \cdot 10$ & $0 \cdot 3$ \\
\hline $0 \cdot 15$ & $0 \cdot 6$ & $0 \cdot 18$ & 0.7 \\
\hline 0.36 & $1 \cdot 6$ & $0 \cdot 32$ & $1 \cdot 4$ \\
\hline 0.26 & $1 \cdot 1$ & 0.51 & $2 \cdot 2$ \\
\hline 0.62 & $2 \cdot 3$ & 0.65 & $2 \cdot 5$ \\
\hline $17 \cdot 58$ & & $17 \cdot 41$ & \\
\hline & & & \\
\hline & & & \\
\hline & & & \\
\hline & & & \\
\hline & & & \\
\hline
\end{tabular}

\begin{tabular}{|c|c|}
\hline \multicolumn{2}{|c|}{$324^{*}$} \\
\hline (a) & (b) \\
\hline $1 \cdot 21$ & $4 \cdot 0$ \\
\hline $7 \cdot 79$ & $29 \cdot 4$ \\
\hline $4 \cdot 07$ & $17 \cdot 3$ \\
\hline $1 \cdot 60$ & 4.8 \\
\hline 2.92 & $11 \cdot 4$ \\
\hline 0.88 & $5 \cdot 2$ \\
\hline $1 \cdot 82$ & $9 \cdot 0$ \\
\hline 0.32 & $1 \cdot 0$ \\
\hline $1 \cdot 30$ & 4.9 \\
\hline 0.76 & $2 \cdot 5$ \\
\hline 0.81 & 2.7 \\
\hline 0.30 & 0.7 \\
\hline 0.40 & $1 \cdot 0$ \\
\hline $0 \cdot 60$ & $1 \cdot 8$ \\
\hline 0.55 & 1.5 \\
\hline $1 \cdot 12$ & $2 \cdot 8$ \\
\hline 26.45 & \\
\hline & \\
\hline & \\
\hline & \\
\hline & \\
\hline
\end{tabular}

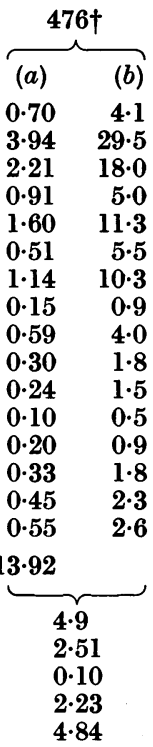

* Material insoluble in saturated ammonium sulphate at $55^{\circ}$.

$\dagger$ Material soluble in saturated ammonium sulphate at $55^{\circ}$. 
Table 4. Amino acid composition of human blood-group Le $e^{a}$ substances

Experimental details are given in the text. Amino acids are expressed as: $(a) \mathrm{g}$. of amino acid/100 g. of substance; $(b) \mu$ moles of amino acid $/ 100 \mu$ moles of total amino acids. Nitrogen is expressed as g./100 g. of substance.

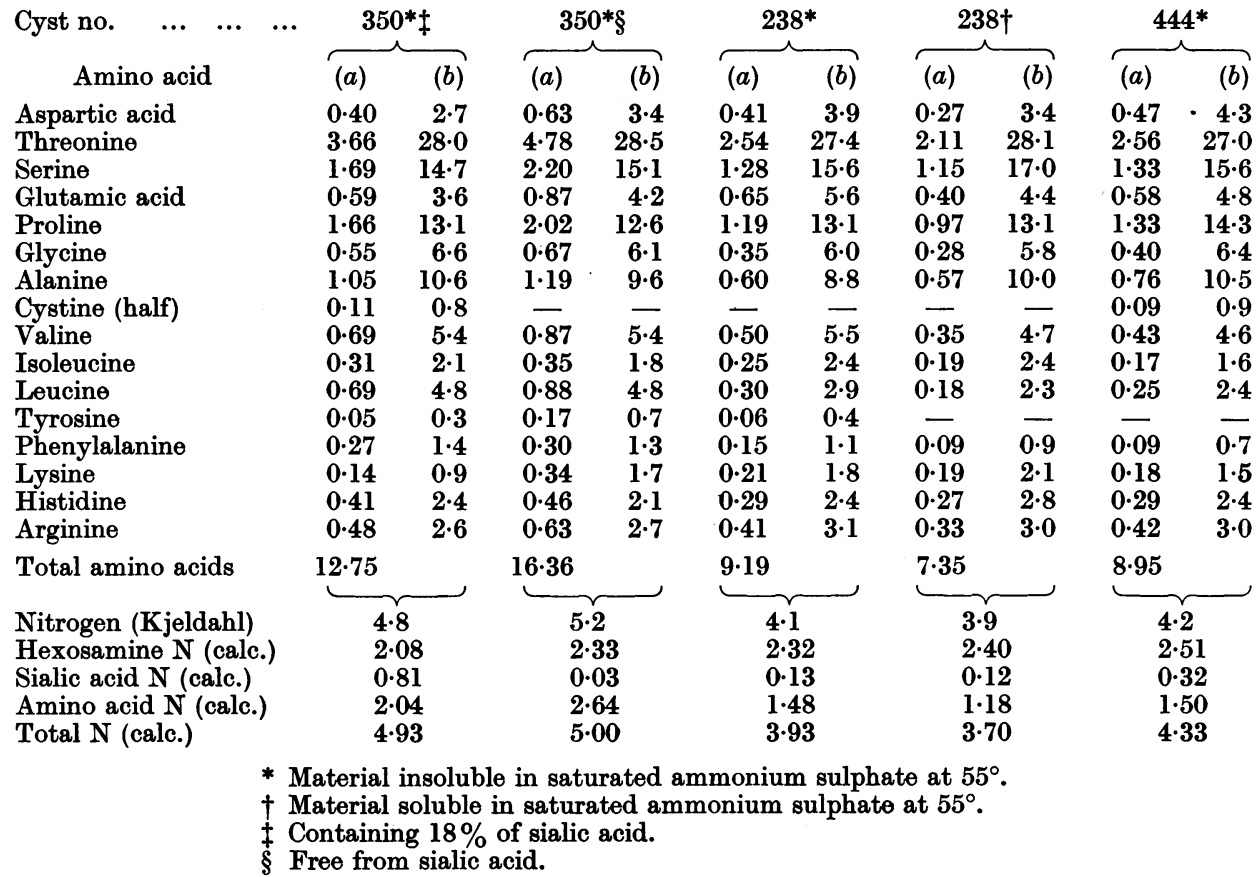

\section{Table 5. Amino acid composition of pig gastric mucin}

Experimental details are given in the text. Amino acids are expressed as: $(a) \mathrm{g}$. of amino acid/100 g. of substance; (b) $\mu$ moles of amino acid $/ 100 \mu$ moles of total amino acids.

\begin{tabular}{|c|c|c|}
\hline Amino acid & $(a)$ & (b) \\
\hline Aspartic acid & $0 \cdot 60$ & $4 \cdot 0$ \\
\hline Threonine & $3 \cdot 00$ & $22 \cdot 5$ \\
\hline Serine & $1 \cdot 82$ & $15 \cdot 4$ \\
\hline Glutamic acid & $0 \cdot 89$ & $5 \cdot 4$ \\
\hline Proline & $2 \cdot 10$ & $16 \cdot 1$ \\
\hline Glycine & 0.52 & $6 \cdot 2$ \\
\hline Alanine & $0 \cdot 77$ & $7 \cdot 7$ \\
\hline Valine & 0.90 & 6.9 \\
\hline Isoleucine & $0 \cdot 30$ & $2 \cdot 0$ \\
\hline Leucine & 0.64 & $4 \cdot 4$ \\
\hline Tyrosine & $0 \cdot 11$ & 0.5 \\
\hline Phenylalanine & $0 \cdot 21$ & 1.2 \\
\hline Lysine & $0 \cdot 28$ & $1 \cdot 7$ \\
\hline Histidine & 0.43 & $2 \cdot 5$ \\
\hline Arginine & $0 \cdot 67$ & $3 \cdot 5$ \\
\hline Total amino acids & $13 \cdot 24$ & \\
\hline
\end{tabular}

single amino acids in the first 2-3 hr. of hydrolysis. It can be accepted therefore that the losses for serine, threonine and aspartic acid found $(10 \cdot 6,6 \cdot 4$ and $5.9 \%$ respectively) are a fairly reliable measure of the destruction of these amino acids and can be used as valid correction factors to obtain values for the amounts of serine, threonine and aspartic acid in blood-group substances.

The amino acids separated, identified and quantitatively determined in the hydrolysis products of the blood-group mucopolysaccharides were aspartic acid, threonine, serine, glutamic acid, proline, glycine, alanine, valine, leucine, isoleucine, phenylalanine, lysine, histidine and arginine. Cystine, methionine and tyrosine were present only in very small amounts and the values obtained were therefore subject to considerable error and are mostly omitted. The blood-group substances contain less than $0.05 \%$ of total sulphur and give no ultraviolet absorption.

The results of the analyses of a number of preparations of blood-group-specific substances, given in Tables 1-5, indicate the closely similar qualitative and quantitative amino acid composition of all the materials, irrespective of the serological specificity of the preparation.

The composition must be considered remarkable and not one that is encountered, so far as we are aware, in any proteins or peptides that have been described previously. The four amino acids, threonine, serine, proline and alanine, together make up about two-thirds of the amino acids present. It is remarkable that the first three of these amino acids 
exist together in such large amounts in the peptide structure. This co-existence indicates that, as blood-group substances are common constituents of many secretions and tissue fluids, this special amino

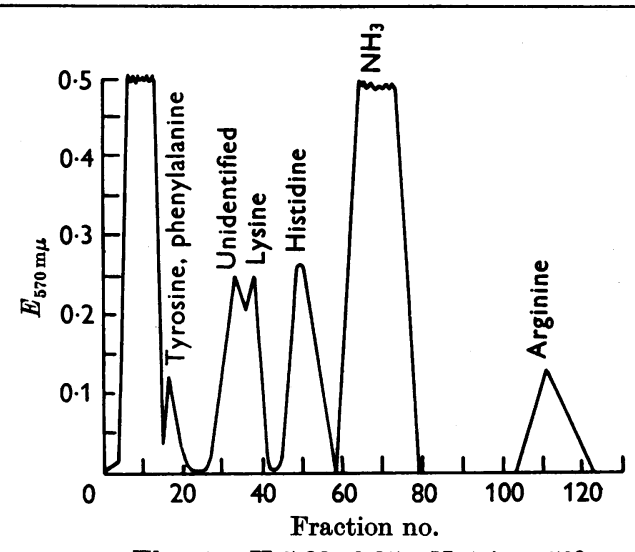

$\leftarrow$ Eluent: $\mathrm{pH} 5 \cdot 28 ; 0.35 \mathrm{M}-\mathrm{Na}{ }^{+}$ion; $50^{\circ} \rightarrow$

Fig. 4. Determination of basic amino acids and ammonia in the hydrolysis products (with $6 \mathrm{~N}-\mathrm{HCl}$ at $114-117^{\circ}$ for $24 \mathrm{hr}$.) of blood-group substance. Separation was made on a $15 \mathrm{~cm}$. Aminex (MS Blend; Q50 grade) resin column. An unidentified substance was eluted together with lysine. Quantitative amino acid determinations (ninhydrin reaction) were made on each $2 \mathrm{ml}$. fraction up to and including fraction 150 .

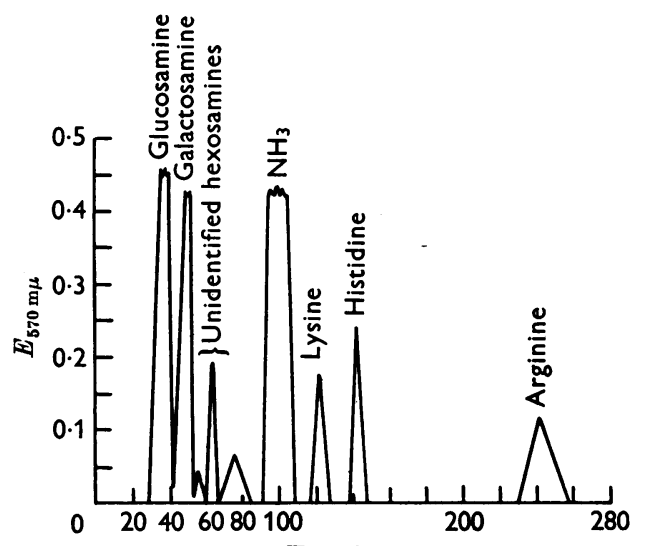

Fraction no.
(a)
(b)

(c)

(a) Eluent: $\mathrm{pH} 4 \cdot 18 ; 0 \cdot 38 \mathrm{M}-\mathrm{Na}^{+}$ion; $30^{\circ}$

(b) $\mathrm{pH} 4 \cdot 18 ; 0.38 \mathrm{M}-\mathrm{Na}^{+}$ion; $50^{\circ}$

(c) $\mathrm{pH} 6.5 ; 0.38 \mathrm{M}-\mathrm{Na}+$ ion; $50^{\circ}$

Fig. 5. Determination of basic amino acids and ammonia in the hydrolysis products (with $6 \mathrm{~N}-\mathrm{HCl}$ at $114-117^{\circ}$ for $24 \mathrm{hr}$.) of blood-group substance. Separation was made on a $50 \mathrm{~cm}$. Aminex (MS Blend; Q 50 grade) resin column. An unidentified substance separated as three materials (fractions 50-85). Quantitative determinations (ninhydrin reaction) were made on each $2 \mathrm{ml}$. fraction up to and including fraction 280 . acid combination must occur very frequently in man (Morgan, 1963).

The qualitative and quantitative composition of all the mucopolysaccharides examined were closely similar, but it is to be observed that the total amount of the amino acid-containing moiety in a blood-group-specific mucopolysaccharide varies considerably. For example, the blood-groupspecific substance no. 324 in Table 3 contained $26 \%$ (g./100 g. of substance) of total amino acids, whereas substance no. 476 contained only about half this amount, and values as low as 7-8 \% of total amino acids were encountered during the investigation of other blood-group substances (Table 4). It appears that the amount of carbohydrate attached to the amino acid-containing structure can vary considerably and apparently does not influence the serological specificity of the resulting macromolecule. However, experiments that would detect the influence on the quantitative serological behaviour of a material that contains a relatively small or large amount of carbohydrate have not, so far as we know, been done.

In spite of the variations in the total amino acid content of individual specimens of blood-groupspecific mucopolysaccharides, the relative amount of each amino acid to all others present is remarkably constant. For example, in most highly purified blood-group substances, threonine falls between 25 and $31 \mu$ moles $/ 100 \mu$ moles, serine between 15 and $20 \mu$ moles $/ 100 \mu$ moles, proline between 12 and $14 \mu$ moles $/ 100 \mu$ moles and alanine between 8 and $11 \mu$ moles $/ 100 \mu$ moles. This remarkably close composition of the amino acid-containing moiety is strong evidence that the blood-group substances examined were free from contamination with foreign protein or carbohydrate-containing proteins, such as the serum $\alpha_{1}$-glycoprotein which contains a considerable amount of the acidic amino acids. A $1 \%$ contamination of the specific mucopolysaccharide with protein would amount to about a $10 \%$ contamination of the amino acidcontaining component and, in view of the very special amino acid composition of the specific substances, this amount of extraneous protein would be readily detected. The introduction of improved techniques to isolate and purify the blood-group substances will probably lead to even smaller variations in the range of amounts of any one amino acid. The observations made so far indicate that blood-group mucopolysaccharides that contain about $30 \mu$ moles of threonine $/ 100 \mu$ moles and less than $4 \mu$ moles of aspartic acid/ $100 \mu$ moles in the amino acid-containing moiety are essentially free from contamination with extraneous protein. The results obtained demonstrate clearly that the amino acid composition of the mucopolysaccharide is under strict control. 
A scheme (Watkins, 1958, 1959, 1962; Watkins \& Morgan, 1959; Ceppellini, 1959) that brings together the known genetical, serological and biochemical data in support of definite pathways for the later stages of the biosynthesis of the bloodgroup-specific mucopolysaccharides postulates that a precursor substance exists which, under the influence of several gene systems, is converted stepby-step, through the addition of the correct sugar units in a precisely ordered manner, into mucopolysaccharides of characteristic blood-group activity. It is envisaged that throughout these metabolic steps no change occurs in the composition of the amino acid-containing residue. The very similar amino acid compositions now demonstrated for preparations of the specific substances strongly support the original hypothesis that postulates that a common peptide backbone structure exists in each specific substance and serves as a common foundation for the carbohydrate additions. It has been envisaged (Morgan, 1954-1955, 1959, 1963) that a possible structural function for the amino acidcontaining moiety is to provide a rigid framework for the attachment of carbohydrate chains and, at the same time, maintain a macromolecular structure in which sugar chains and, in particular, their non-reducing end groups are held in some definite relationship to each other and to the rest of the molecule, and, in this way, control the quantitative serological behaviour of the blood-group substances.

Now that an amino acid-containing residue is firmly established as an integral part of all bloodgroup substances and the qualitative and quantitative composition of these components is known to be closely similar in all materials, irrespective of specificity within the $\mathrm{ABO}$ and $\mathrm{Le}^{\mathrm{a}}$ blood-group systems, it was decided to determine whether this component has a clearly-defined specific immunological function. The results of several experimental studies indicate that the amino acid-containing residue plays no active part as a structure directly responsible for blood-group specificity. Evidence is already accumulating, however, that suggests that this component is probably a factor of primary importance in the immunological phenomenon of delayed hypersensitivity (Holborow \& Loewi, 1962; Jankovic \& Waksman, 1962). The capacity of all blood-group-specific mucopolysaccharides, when mixed with Freund's adjuvant and injected intradermally into guinea pigs, to evoke a delayed hypersensitivity reaction to a later skin injection of homologous or heterologous bloodgroup substance indicates that there is in these materials a chemical structure that is to be found in all the specific substances and is responsible for the common serological specificity. It is most probably the amino acid-containing residue in each substance that is the active agent, the cross-reactivity of which might be expected in view of the very close composition of these structures in all blood-group substances. Fragments obtained from the bloodgroup substances by enzymic or mild acid or alkaline hydrolysis, under conditions that preferentially eliminate carbohydrate units from the macromolecule and leave the amino acid-containing structure essentially unchanged, can be expected to have an increased capacity to evoke a delayed hypersensitivity reaction, and thus to establish more precisely the part played by the peptide moiety in the phenomenon of delayed hypersensitivity. As the optical form of each amino acid and their sequence in the peptide residues of blood-group substances are not yet known, the fact that the amino acid composition is closely similar in all materials, and the finding that a few amino acids dominate the quantitative composition of the peptide moiety, do not allow us to conclude that the amino acidcontaining structures are identical in all human blood-group-specific mucopolysaccharides.

\section{SUMMARY}

1. Conditions for the satisfactory hydrolysis of human blood-group substances and the quantitative determination of their amino acids have been established.

2. The amino acid composition of each of more than twenty individual blood-group-specific mucopolysaccharides were closely similar, irrespective of the serological specificity within the ABO and Lewis blood-group systems.

3. Possible functions for the amino acid-containing moiety of the mucopolysaccharide macromolecules are discussed.

We thank Dr R. A. Kekwick and Dr M. Creeth for examining the materials investigated for electrophoretic and ultracentrifugal behaviour, and Mr K. Travis for much excellent technical help. The work has been supported by a grant from the Medical Research Council.

\section{REFERENCES}

Ames, B. N. \& Mitchell, H. K. (1952). J. Amer. chem. Soc. 74, 252.

Ames, B. N. \& Mitchell, H. K. (1955). J. biol. Chem. 212, 687.

Aminoff, D., Morgan, W. T. J. \& Watkins, W. M. (1950). Biochem. J. 46, 426.

Bendich, A., Kabat, E. A. \& Bezer, A. E. (1946). J. exp. Med. 83, 485.

Brand, E. \& Saidel, L. J. (1946). J. exp. Med. 83, 497.

Carsten, M. E. \& Kabat, E. A. (1956). J. Amer. chem. Soc. 78, 3083.

Caspary, E. A. (1954). Biochem. J. 57, 295.

Ceppellini, R. (1959). Ciba Found. Symp.: Biochemistry of Human Genetics, p. 242. London: J. and A. Churchill Ltd. 
Dawson, R. M. C., Elliott, D. C., Elliott, W. H. \& Jones, K. M. (eds.) (1959). Data for Biochemical Research, p. 286. Oxford: Clarendon Press.

Dustin, J. P., Czajkowska, C., Moore, S. \& Bigwood, E. J. (1953). Analyt. chim. Acta, 8, 256.

Elson, L. A. \& Morgan, W. T. J. (1933). Biochem. J. 27, 1824.

Freudenberg, K., Walch, H. \& Molter, H. (1940). Naturwissenschaften, 30, 87.

Frisell, W. R., Meech, L. A. \& Mackenzie, C. G. (1954). J. biol. Chem. 207, 709.

Gibbons, R. A. \& Morgan, W. T. J. (1954). Biochem. J. 57, 283.

Gibbons, R. A., Morgan, W. T. J. \& Gibbons, M. N. (1955). Biochem. J. 60, 428.

Holborow, E. J. \& Loewi, G. (1962). Immunology, 5, 278.

Jankovic, B. D. \& Waksman, B. H. (1962). J. Immunol. 89, 606.

Jepson, J. B. \& Smith, I. (1953). Nature, Lond., 172, 1100.

Kekwick, R. A. (1950). Biochem. J. 46, 438.

Landsteiner, K. \& Harte, R. A. (1940). J. exp. Med. 71, 551.

Landsteiner, K. \& Harte, R. A. (1941). J. biol. Chem. 140, 673.

Ma, T. S. \& Zuazaga, G. (1942). Industr. Engng. Chem. (Anal.), 14, 280.

Markham, R. (1942). Biochem. J. 36, 790.

Martin, C. J. \& Axelrod, A. E. (1953). Proc. Soc. exp. Biol. N.Y., 83, 461.
Moore, S., Spackman, D. H. \& Stein, W. H. (1958). Analyt. Chem. 30, 1185.

Moore, S. \& Stein, W. H. (1954). J. biol. Chem. 211, 893.

Morgan, W. T. J. (1947). Experientia, 3, 257.

Morgan, W. T. J. (1954-1955). Scientific Basis of Medicine, vol. 4, p. 92. University of London.

Morgan, W. T. J. (1959). Int. Symp. on Biologically Active Mucoids, p. 6. Warsaw: Polska Akademia Nauk.

Morgan, W. T. J. (1963). Ann. N.Y. Acad. Sci. 108 (2), 177.

Morgan, W. T. J. \& King, H. K. (1943). Biochem. J. 37, 640.

Morgan, W. T. J. \& Pusztai, A. (1961). Biochem. J. 81, 648.

Neuman, R. E. \& Logan, M. A. (1950). J. biol. Chem. 184, 299.

Pusztai, A. \& Morgan, W. T. J. (1961). Biochem. J. 80, 107.

Rees, M. W. (1946). Biochem. J. 40, 632.

Rondle, C. J. M. \& Morgan, W. T. J. (1955). Biochem. J.61, 586.

Ryle, A. P., Sanger, F., Smith, L. F. \& Kitai, R. (1955). Biochem. J. 60, 541.

Warren, L. (1959). J. biol. Chem. 234, 1971.

Watkins, W. M. (1958). Proc. 7th Congr. int. Soc. Blood Transfusion, Rome, p. 206.

Watkins, W. M. (1959). Ciba Found. Symp.: Biochemistry of Human Genetics, p. 217. London: J. and A. Churchill Ltd.

Watkins, W. M. (1962). Immunology, 5, 245.

Watkins, W. M. \& Morgan, W. T. J. (1959). Vox sang., Basel, 4, 97.

Biochem. J. (1963) 88, 555

\title{
The Accumulation of Ribonucleic Acid by a Mutant of Escherichia coli
}

\author{
By S. DAGLEY, G. TURNOCK AND D. G. WILD \\ Department of Biochemistry, The University, Leeds 2
}

(Received 21 March 1963)

In bacteria, protein synthesis is normally closely linked to the synthesis of RNA, so that, if the synthesis of one is diminished or stopped, that of the other is similarly affected. Under certain conditions, however, protein synthesis can be sharply retarded while synthesis of RNA is less affected; in these circumstances the bacteria therefore accumulate RNA. These abnormal conditions can be produced by treating Escherichia coli with chloramphenicol or puromycin; the RNA synthesized during incubation with either of these antibiotics has been extensively studied, e.g. by Hahn, Schaechter, Cezlowski, Hopps \& Ciak (1957), Neidhardt \& Gros (1957), Yarmolinski \& de la Haba (1959), Takeda, Hayashi, Nakagawa \& Suzuki (1960) and Aronson \& Spiegelman $(1961 a, b)$.

Another instance in which cells can accumulate RNA has also been described. In general, bacterial mutants requiring an amino acid for growth no longer synthesize protein and RNA when the essential amino acid is withdrawn (Pardee \& Prestridge, 1956). However, Borek, Ryan \& Rockenbach (1955) discovered that, if the methionine-requiring mutant $58-161$ of $E$. coli $\mathrm{K} 12$ is starved of methionine, protein synthesis stops but RNA continues to be made; Fleissner \& Borek (1962) have investigated in some detail the 'transfer' RNA that is synthesized during methioninestarvation. Stent \& Brenner (1961) have shown that the ability of this mutant to synthesize RNA in the absence of protein synthesis is genetically determined. By suitable conjugation experiments, mutants requiring amino acids other than methionine can be obtained which synthesize RNA when their 'new' amino acid requirement is withdrawn. Apparently there exists a locus on the bacterial chromosome which in this strain produces a less stringent control of RNA synthesis. The site of this locus in relation to known genetic markers has been established (Alfoldi, Stent \& Clowes, 1962). 